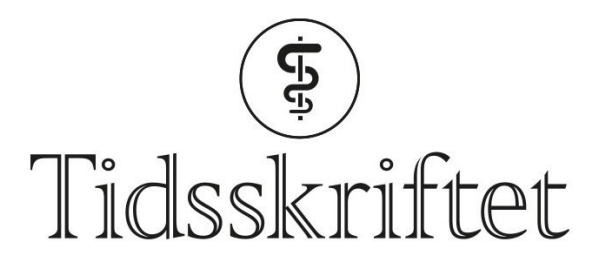

DEN NORSKE LEGEFORENING

\title{
Livsstil og genetikk påvirker risiko for demens
}

FRA ANDRE TIDSSKRIFTER

PETTER MORTEN PETTERSEN

Tidsskriftet

Både livsstilsfaktorer og genetikk er av betydning for risikoen for å utvikle demens, viser en ny studie.

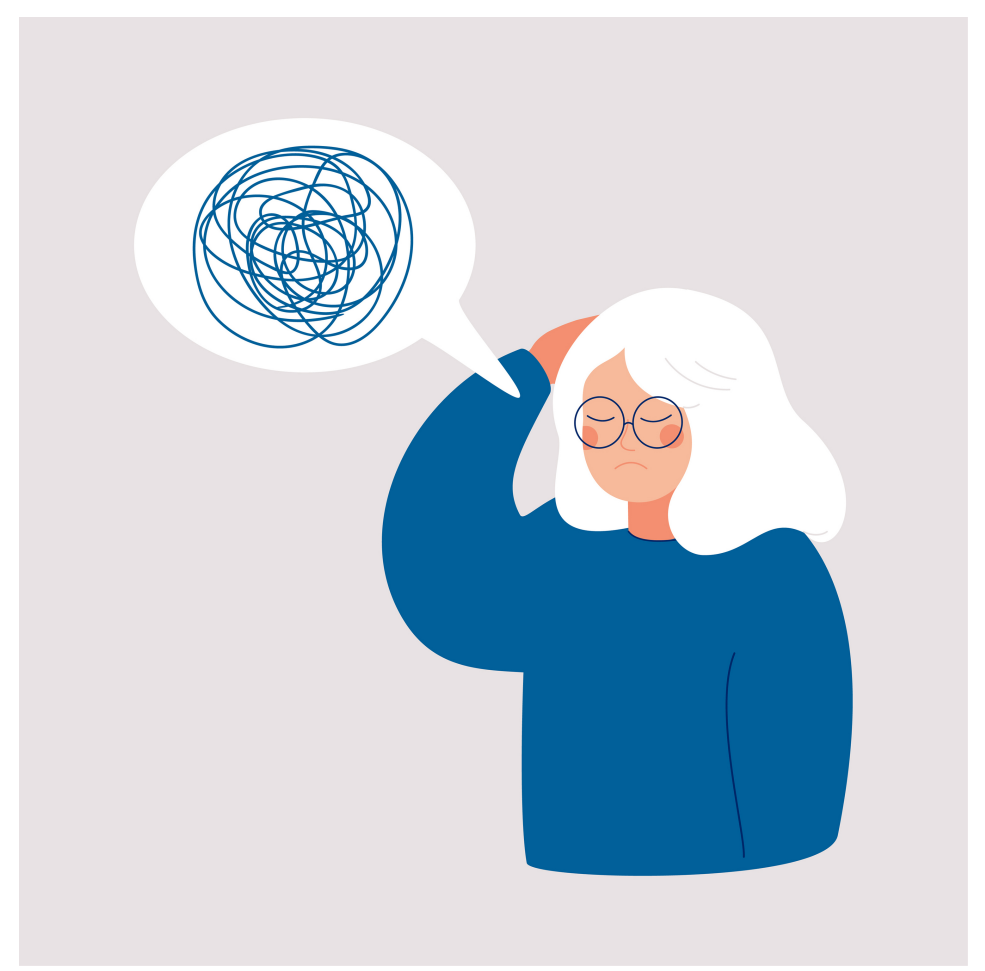

Illustrasjon:ponomariova_maria/iStock

I en nylig publisert britisk studie ønsket man å kartlegge om livsstilsfaktorer var koblet til demensrisiko uavhengig av genetisk risiko (1). Dataene ble hentet fra et britisk pasientregister og biobank.

Omtrent 200 ooo personer ble fulgt i rundt åtte år (median). Basert på deres svar på spørreskjema ble livsstilen kategorisert som fordelaktig (68\%), noe uheldig (intermediate) $(24 \%)$ og uheldig $(8 \%)$. Genetisk risiko for demens ble kategorisert som lav $(20 \%)$, intermediær (60\%) og høy (20\%).

I gruppen personer med høy genetisk risiko utviklet 1,23\% demens, mot o,63\% i gruppen 
med lav genetisk risiko (justert hasardratio 1,91; $95 \% \mathrm{KI}$ 1,64-2,23). I gruppen med høy genetisk risiko og uheldig livsstil utviklet 1,78 \% demens, mot 0,56\% hos dem med både lav genetisk risiko og fordelaktig livsstil (hasardratio 2,83; 2,09-3,83). Kombinasjonen høy genetisk risiko og fordelaktig livsstil ga en risiko for demensutvikling på 1,13\%, mot 1,78 \% hos dem med høy genetisk risiko og uheldig livsstil (hasardratio o,68; o,51-0,90).

- Dette er en interessant og viktig studie der man har greid å kombinere informasjon om genetisk risiko og livsstilsrisiko for demens i et svært stort materiale, sier professor Geir Selbæk, som er psykiater og forskningssjef i Nasjonal kompetansetjeneste for aldring og helse. - Funnene i studien er ikke overraskende og bygger opp under mange studier de siste årene som viser at en rekke modifiserbare livsstilsfaktorer påvirker risikoen for demens. Et viktig og relativt nytt funn er at risikoen for demens forbundet med livsstilsfaktorer er til stede uavhengig av den genetiske risikoen for demens, sier Selbæk, som mener resultatene i stor grad er overførbare til norske forhold.

\section{LITTERATUR:}

1. Lourida I, Hannon E, Littlejohns TJ et al. Association of Lifestyle and Genetic Risk With Incidence of Dementia. JAMA 2019;322: 430-7. [PubMed][CrossRef]

Publisert: 7. oktober 2019. Tidsskr Nor Legeforen. DOI: 10.4045/tidsskr.19.0508

(C) Tidsskrift for Den norske legeforening 2020. Lastet ned fra tidsskriftet.no 